\title{
Nitrogen Fixation in the Rumen of a Living Sheep
}

\author{
By P. N. HOBSON AND R. SUMMERS \\ Rowett Research Institute, Bucksburn, Aberdeen, AB2 $95 B$ \\ AND J. R. POSTGATE AND D. A. WARE \\ Unit of Nitrogen Fixation, University of Sussex, Brighton, BNI $9 Q J$
}

\section{(Received 22 January 1973)}

The possibility that rumen bacteria fix nitrogen has been considered for many years. Though the rumen atmosphere consists mainly of methane and carbon dioxide, some nitrogen enters in swallowed air, and quite large amounts may diffuse into the rumen contents from the blood vessels in the rumen wall. Moisio, Kreula \& Virtanen (1969) found no evidence for fixation of ${ }^{15} \mathrm{~N}_{2}$ from gas bubbled into the rumen for a short time, but more recently Granhall \& Ciszuk (197I) and Elleway, Sabine \& Nicholas (I97I) showed that samples of sheep rumen contents had a very small acetylene reduction capacity in vitro, corresponding to fixation of about $1 \mathrm{mg} \mathrm{N} /$ sheep/day. We had tested rumen contents from a number of cows, sheep, red deer and reindeer on diets rather different from those used by these workers, but using a similar method in which I $g$ of rumen contents was incubated at $38{ }^{\circ} \mathrm{C}$ under $\mathrm{I} 6 \mathrm{ml}$ argon +0.2 or $0.4 \mathrm{ml}$ acetylene as soon as possible after sampling. Our results were essentially similar: in a number of sheep fed on maize + hay, hay + grass cubes, dried grass + concentrates, hay + concentrates, hay + dried grass, all concentrates; in cows fed on barley or dried grass + concentrates; and in red deer and reindeer on natural pastures, the acetylene reduction was small and variable with a maximum about $\mathrm{I} \cdot 9 \mathrm{nmol} / \mathrm{g}$ rumen contents/h. There seemed to be no correlation between diet and activity, nor between rumen contents incubated anaerobically or with an oxygen content equivalent to the maximum amount of oxygen noted in various samples of rumen gas.

Some early tests (Postgate, I97I) gave much lower acetylene reduction rates. In these, samples had been cooled and delays up to 2 days had preceded testing. It seemed possible that the acetylene reduction activity might be affected by cooling or the brief exposure of the rumen sample to air during the process of setting up the tests, so two series of experiments were planned, one in which sampling was performed so as to avoid such stresses, the other in which sampling was avoided altogether by using a cannulated sheep.

To avoid cooling and aeration, the rumen contents were drawn from deep in the rumen, into a tube initially filled with argon. The tube was kept warm while its outside was cleaned, weighed to determine its contents of rumen fluid and acetylene then injected. The tube was incubated on its side at $39{ }^{\circ} \mathrm{C}$ for $4 \mathrm{~h}$. About $5 \mathrm{~g}$ rumen contents and $0.4 \mathrm{ml}$ acetylene were used in a tube of $12 \mathrm{ml}$ total volume. The results for a sheep fed on hay + dried grass varied from 0.59 to I $.0 \mathrm{I}$ nmol acetylene reduced/g rumen contents/h, at intervals up to $7.5 \mathrm{~h}$ after the morning feed. These results were in the same range as those found previously and showed that the method of sampling had no effect.

To determine whether the potential to fix $\mathrm{N}_{2}$ was similar in vivo, a rubber diaphragm was fitted over the rumen cannula of a sheep and the animal left for some hours while rumen gases, possibly disturbed by fitting the diaphragm, re-equilibrated. Acetylene $(250 \mathrm{ml}$; or in the last experiment $350 \mathrm{ml}$ ) was then injected into the rumen gas. After I to $2 \mathrm{~min}$ a 
'zero-time' sample of rumen gas $(5 \mathrm{ml})$ was taken with a syringe and injected into a $17 \mathrm{ml}$ tube containing argon from which $5 \mathrm{ml}$ had been previously removed by syringe. Similar gas samples were taken at intervals and later analysed for acetylene, ethylene and methane, in a Pye 104 gas chromatograph, with a $70 \mathrm{~cm}$ column, as described by Postgate (1972). The acetylene content of the gas diminished rapidly over the first $30 \mathrm{~min}$, presumably due to absorption into tissues and rumen fluid, and eructation, and then declined more steadily. The losses of ethylene were assumed to equal those of acetylene calculated from the change in acetylene concentration in the gas between any two sampling times; from these figures and the ethylene content of the gas samples a measure of ethylene production between the sampling times could be made. In five tests on two sheep fed on dried grass and concentrates or hay, or hay and grass cubes, samples were taken at intervals of 10 min or more for up to $6 \mathrm{~h}$ after morning feeding. The rates of ethylene production were variable, but with no obvious pattern with time. The average ethylene production in all samples, after the first $30 \mathrm{~min}$, was $\mathrm{I} \cdot 2 \mathrm{nmol} / \mathrm{ml}$ rumen gas $/ \mathrm{h}$, with maximum and minimum values of $5 \cdot \mathrm{I}$ and $\mathrm{o}$. Over the first $30 \mathrm{~min}$ it was apparently higher, but over this time rapid changes in acetylene concentration were taking place which made calculations unreliable. For maximum ethylene production, acetylene concentration in the gas phase must exceed double the $K_{m}$ for acetylene reduction ( $0.0 \mathrm{I}$ atm $\mathrm{C}_{2} \mathrm{H}_{2}$ ). Considering only results after the first $30 \mathrm{~min}$, the acetylene concentration was sometimes below $2 \times K_{m}$, but no systematic effects of acetylene concentration on reduction rate were noted.

Rumen gas volumes estimated from the amount of acetylene injected and the concentration of acetylene in the zero-time gas samples, were about 350, 500, 790, I 3 I 0 and I $500 \mathrm{ml}$ in the different experiments. Taking the average ethylene production quoted above and a rumen gas volume of $1500 \mathrm{ml}$, a possible average rate of nitrogen fixation is $0.4 \mathrm{mg} / \mathrm{sheep} /$ day, of the same order as in the tests in vitro and of the same order as reported by other workers. In comparison with the nitrogen requirements of the sheep it is negligible. Such a level of nitrogen fixation would have been undetectable in the experiments of Moisio et al. (I969) where ${ }^{15} \mathrm{~N}_{2}$ was bubbled into the rumen for $30 \mathrm{~min}$ and the rumen contents then tested for nitrogen isotopes. Similarly, the acetylene-reduction tests explain the lack of definite positive results in our own experiments, where rumen contents or bacterial fractions were incubated under ${ }^{15} \mathrm{~N}_{2}$ for $20 \mathrm{~h}$ and the isotope abundance of nitrogen compounds determined.

The results show that the slight and variable ability of samples of rumen contents to reduce acetylene reflects the actual situation in vivo. It is probably due to free-living, nitrogen-fixing bacteria entering the rumen with food and from the surroundings; small numbers of such contaminants are always present in the rumen.

\section{REFERENCES}

Elleway, R. F., Sabine, J. R. \& Nicholas, D. J. B. (1971). Acetylene reduction by rumen microflora. Achiv fïr Mikrobiologie 76, 277-291.

Granhall, U. \& CiszUK, P. (197I). Nitrogen fixation in rumen contents indicated by the acetylene reduction test. Journal of General Microbiology 65, 91-93.

Moisio, T., Kreula, M. \& Virtanen, I. (1969). Experiments on nitrogen fixation in cow's rumen. Sliomen Kemistilchti 92, 432-433.

Postgate, J. R. (197I). Biochemical and physiological studies with free-living, nitrogen-fixing bacteria. Plant and Soil, special volume, pp. 55I-559. Edited by T. A. Lie and E. G. Mulder. The Hague: Nÿhoff.

Postgate, J. R. (I972). The acetylene reduction test for nitrogen fixation. In Methods in Microbiology, 6b, pp. 343-356. Edited by J. R. Norris and D. W. Ribbons. London: Academic Press. 